EESTI NSV TEADUSTE AKADEEMIA TOIMETISED. 24. KOIDE

KEEMIA * GEOLOOGIA. 1975, NR. 1

ИЗВЕСТИЯ АКАДЕМИИ НАУК ЭСТОНСКОП ССР. ТОМ 24 ХИМИЯ * ГЕОЛОГИЯ. 1975, № 1

удК $575: 564.52(474.2)$

Х. СТУМБУР

\title{
БИОМЕТРИЧЕСКАЯ ХАРАКТЕРИСТИКА РАКОВИНЫ СОВРЕМЕННОГО НАУТИЛУСА
}

Раковина современного наутилуса является благоприятным объектом для исследования биометрическими методами, так как она отражает все стадии онтогенетического развития, признаки которых легко подвергаются измерениям (Шиманский, 1948; Балашов, 1953; Стумбур, 1960; Hamada, 1964). Благодаря своеобразному строению раковины для восстановления ее онтогенеза не требуется большото количества экземпляров. Однако для уточнения продолжительности отдельных стадий онтогенеза (эмбриональной и постэмбриональной стадий) и выявления закономерностей изменения некоторых признаков, которые из-за сильной вариации у одного экземпляра оказываются неуловимыми (напр., изменения положения сифона), требуется бо̀льшее количество экземпляров.

Исходя из указанного выше биометрически были исследованы 24 раковины Nautilus pompilius L. и одна раковина Nautilus macromphalus Sow. с Соломоновых островов из коллекции Х. Мутвея, котарый любезно передал их в распоряжение автора. К ним прибавились данные измерения двух раковин Nautilus pompilius из коллекции Тартуского государственного университета (Стумбур, 1960). Измеренный и сфотографированный материал, а также данные измерений хранятся в палеозоологическом отделе Государственного музея в Стокгольме и в Геологическом музее АН ЭССР.

Для изучения изменений длины воздушных камер и положения сифона были изготовлены продольные разрезы по плоскости симметрии 22 раковин Nautilus pompilius и одной раковины Nautilus macromphalus. Перед распиливанием раковин были замерены их максимальный диаметр, высота и ширина устья. Для выяснения изменения соотношении ширины оборота к его высоте, а также изменения очертания поперечного сечения оборота были изготовлены поперечные разрезы четырех раковин Nautilus pompilius на разных стадиях развития.

Наиболее интересными оказались измеренные по вентральной стороне раковины данные о длине жилой ка ме ры Nautilus pompilius. Bыяснилось, что при равномерном росте раковины длина жилой камеры увеличивается скачкообразно, соответственно периодическому выделению перегородок. После каждой очередной передвижки мягкого тела животного в раковине и об́разования перегородки длина жилой камеры становится короче (рис. 1) ее длины до образования септы. Механизм передвижки мягкого тела хорошо совпадает с механизмом образования перегородок и сифональной трубки, описанным Х. Мутвеем (Mutvei, 1967). 


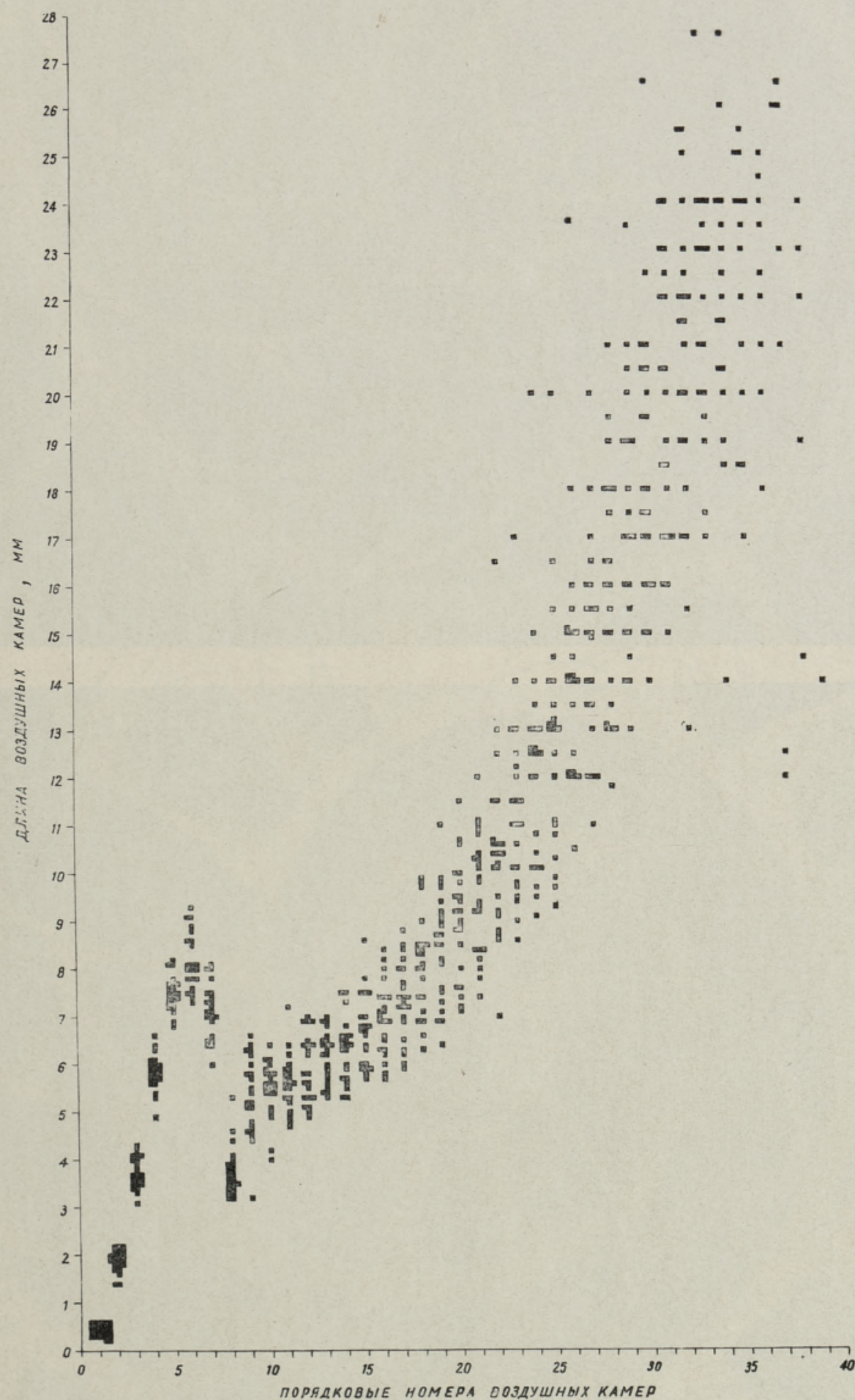

Онтогенетические изменения длины воздушных камер у Nautilus pompilius L. по данным измерений 22 раковин. 
Таблица II
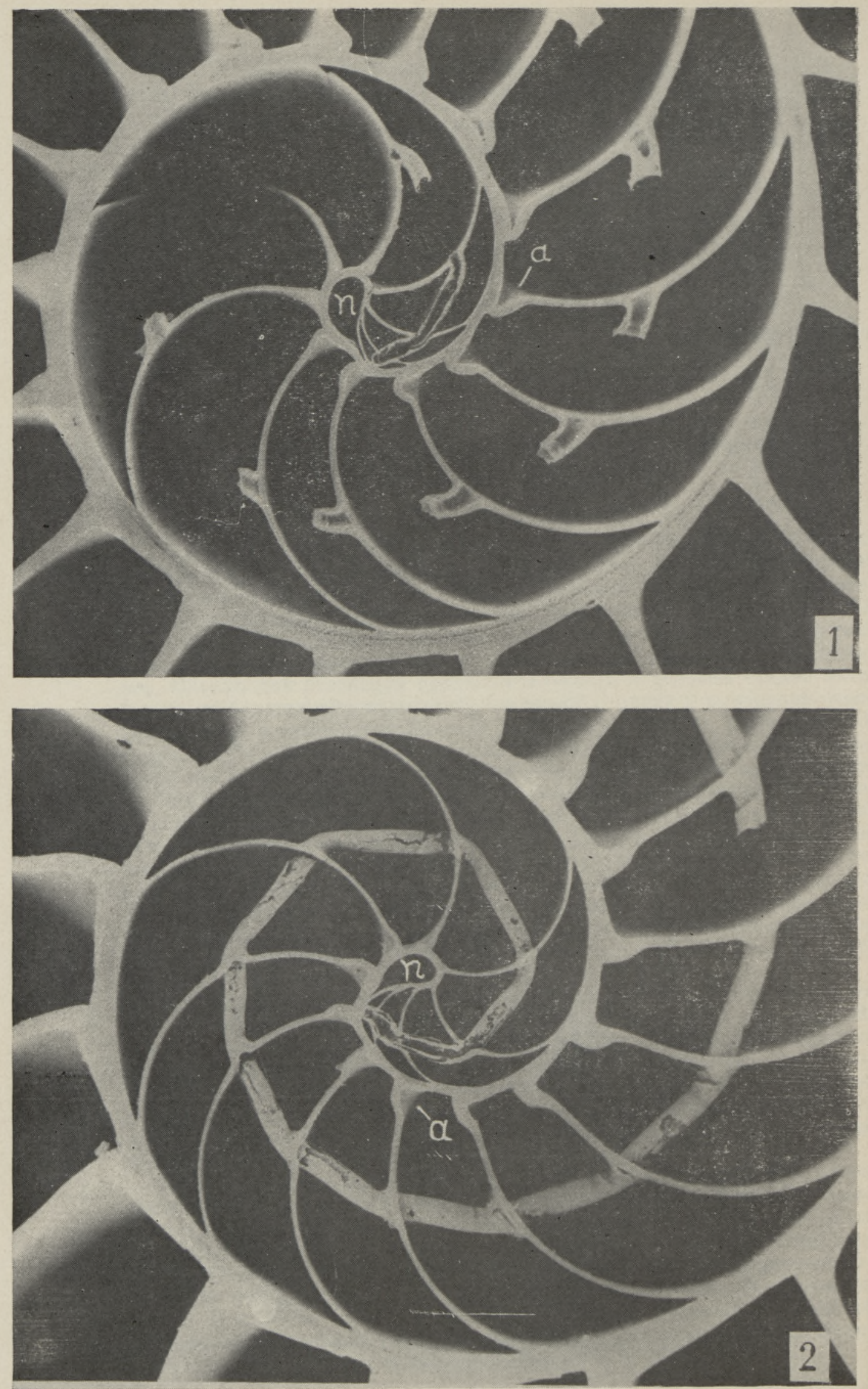

Продольные разрезы начальной части раковин

Фиг. 1. Nautilus pompilius L. $(\times 5,85)$, экз. № Со 11. Фиг. 2. Nautilus macromphalus Sow. $(\times 5,08)$. экз. № Со 25. $n-$ умбональное отверстие, $a-$ аннулярная ямка. 
Длин а воздушных ка ме р измерялась также по вентральной стороне раковины (рис. 2) от места прикрепления перегородки к стенке раковины до места примыкания следующей перегородки. Из рис. 3 и табл. I видно, что эволюция раковины Nautilus pompilius проходит два хорошо обособленных этапа. На ранней стадии развития (до 8 камеры) длина воздушных камер интенсивно увеличивается. После образования восьмой, очень короткой камеры их рост продолжается, причем вначале этот процесс происходит медленно, а после образования примерно 20 камер - более быстрыми темпами. В геронтической стадии развития рост раковины опять замедляется, при этом образуется одна или две очень коропкие воздушные камеры. Аналогичные изменения в окорости роста раковины происходят и в онтогенезе Nautilus macromphalus (рис. 3). По-видимому, начальные стадии развития раковин обоих видов были приблизительно одинаковой продолжительности.
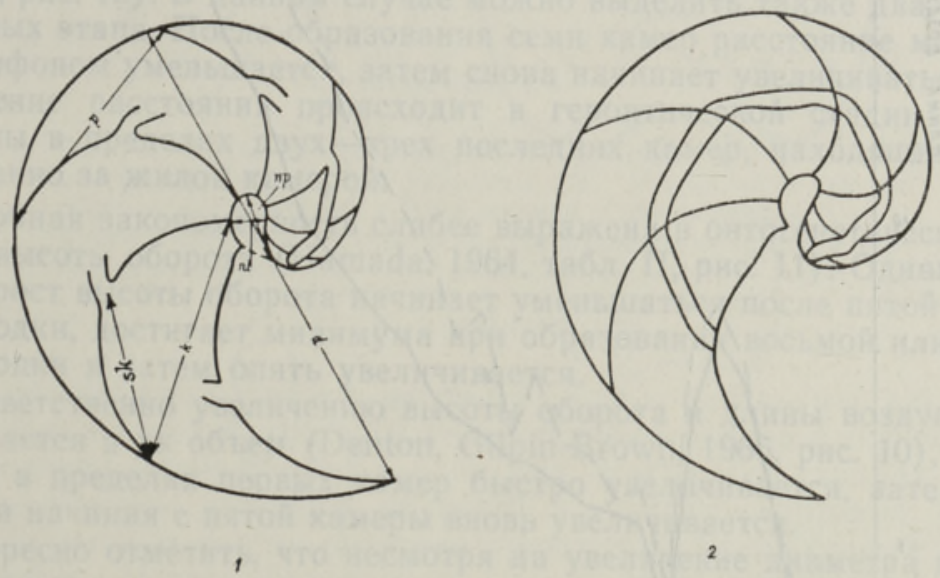

2

Рис. 2. Схемы строения фрагмокона эмбриональных раковин: 1 - Nautilus pompilius L. $(\times 3,1)$, рисунок сделан по начальной части раковины экз. № Сo $11 ; d$ - диаметр эмбрионального фрагмокона, $n p$ - длина умбонального отверстия, $n l-$ его ширина, $k-$ высота оборота, sk - расстояние сифона от вентральной стороны раковины, $p$ - длина воздушной камеры. 2 - Nautilus macromphalus Sow. $(\times 2,9)$, рисунок сделан по начальной части рақовины экз. № Co 25.

Изменчивость длины воздушных камер у Nautilus pompilius в молодых стадиях развития раковины относительно небольшая. Длина четвертой камеры колеблется от 4,9 до 6,6 мм (табл. I). С возрастом раковины этот показатель значительно увеличивается. Например, во взрослой стадии развития раковины длина 26-й камеры колеблется от 10,6 до 23,7 мм.

Такая же закономерность наблюдается и в онтогенетических изменениях расстояния последующей перегородки от сифона (Hamada, 1964, 


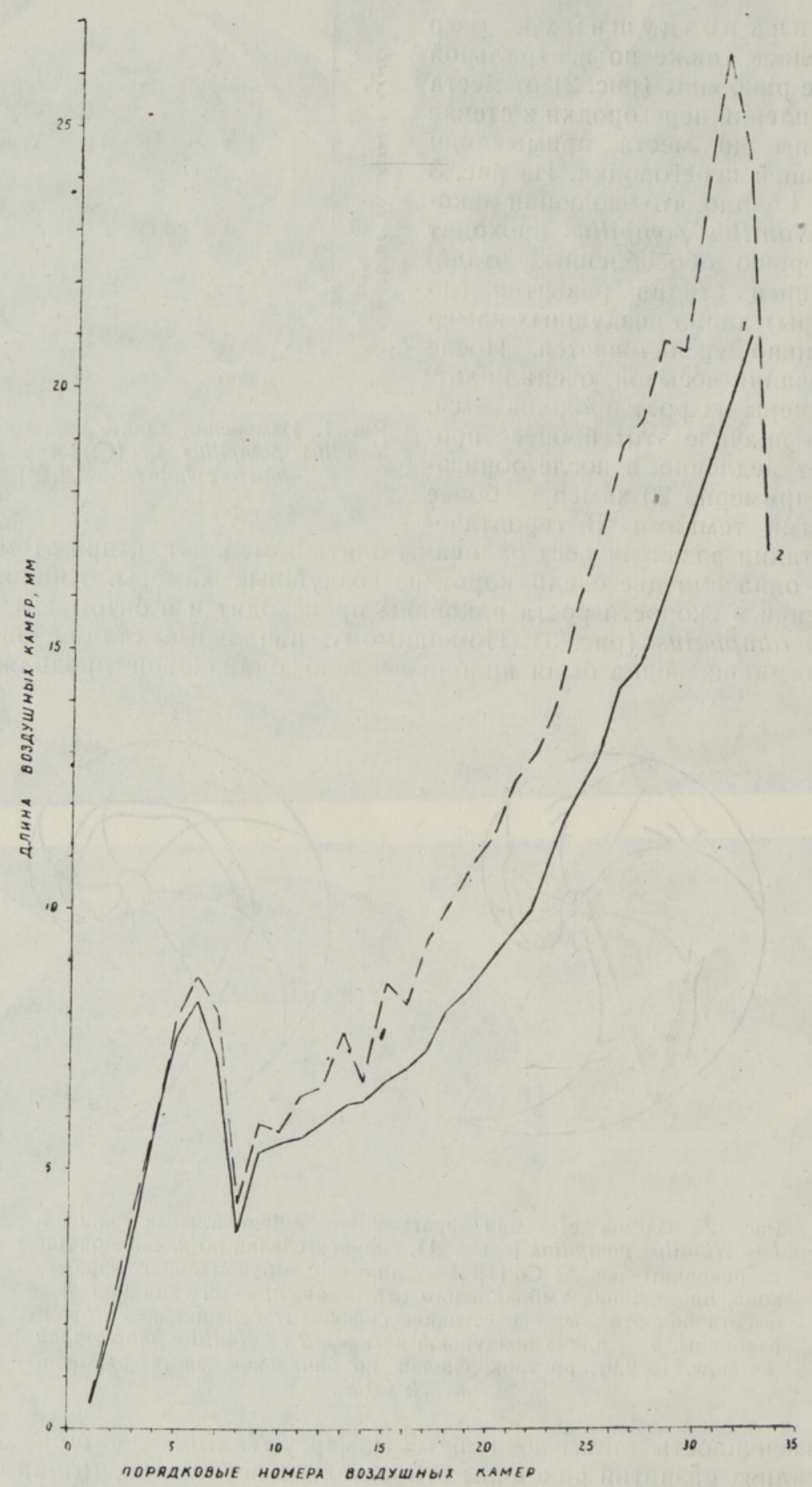

Рис. 3. Онтогенетические изменения длины воздушных камер у Nautilus pompilius L. (1) по средним значениям длины камер 22 раковин и у Nautilus macromphalus Sow. (2). 

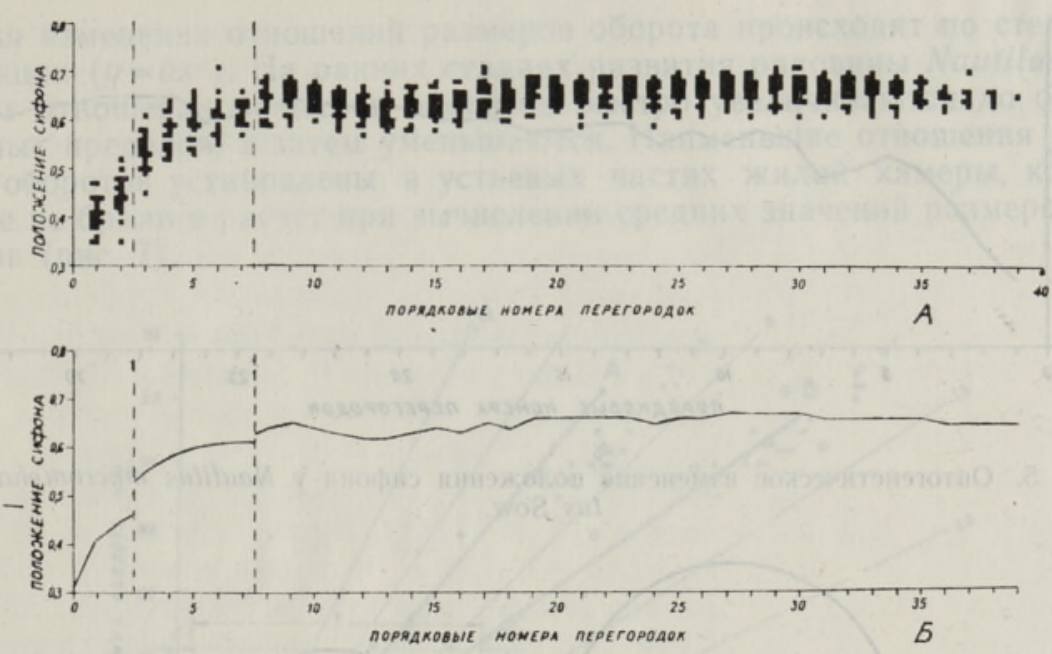

Рис. 4. Онтогенетическое изменение положения сифона у Nautilus pompilius L.: $A$ - по данным измерений 20 раковин, $E$ - по средним значениям положения сифона 20 раковин. Вертикальными прерывистыми линиями обозначены разные стадии эмбрионального развития раковины.

табл. II, рис. 10). В данном случае можно выделить также два ясно обособленных этапа. После образования семи камер расстояние между септой и сифоном уменьшается, затем снова начинает увеличиваться. Новое сокращение расстояния происходит в геронтической стадии развития раковины в пределах двух-трех последних камер, находящихся непосредственно за жилой камерой.

Подобная закономерность слабее выражена в онтогенетических изменениях высоты оборота (Hamada, 1964, табл. II, рис. 11). Однако видно, что прирост высоты оборота начинает уменьшаться после пятой-шестой перегородки, достигает минимума при образовании восьмой или девятой перегородки и затем опять увеличивается.

Соответственно увеличению высоты оборота и длины воздушных камер меняется и их объем (Denton, Gilpin-Brown, 1966, рис. 10), который сначала в пределах первых камер быстро увеличивается, затем уменьшается и начиная с пятой камеры вновь увеличивается.

Интересно отметить, что несмотря на увеличение диаметра и объема воздушных камер в онтогенезе рост спирали раковины после образования нескольких воздушных камер происходит в пониженном темпе (Шиманский, 1948).

Для исследования изменений положения с ифон а измерялось его расстояние от вентральной стороны раковины и высота оборота в контактовых частях перегородок со стенкой раковины, а затем рассчитывалось их отношение. Как видно из рис. 4, сифон Nautilus pompilius достигает положения, характерного для взрослой раковины, уже в шестой камере. Некоторое смещение сифона к вентральной стороне́ раковины в юношеской стадии развития обусловлено возникновением в этот период аннулярной ямки (табл. II). Более четкие изменения уровня колебаний положения сифона происходят после образования второй и седьмой перегородок (рис. 4). Положение сифона Nautilus macromphalus (рис. 5) претерпевает в общем такие же изменения, но из-за единичности экземпляра и сильной изменчивости данного признака изменения уровня колебаний положения сифона на рисунке отражены недостаточно. 


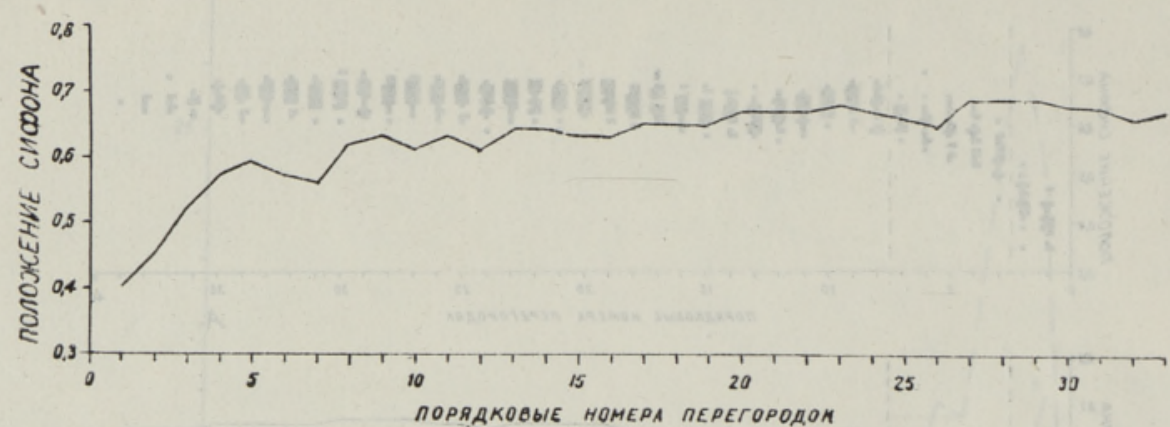

Рис. 5. Онтогенетическое изменениє положения сифона у Nautilus macromphalus Sow.

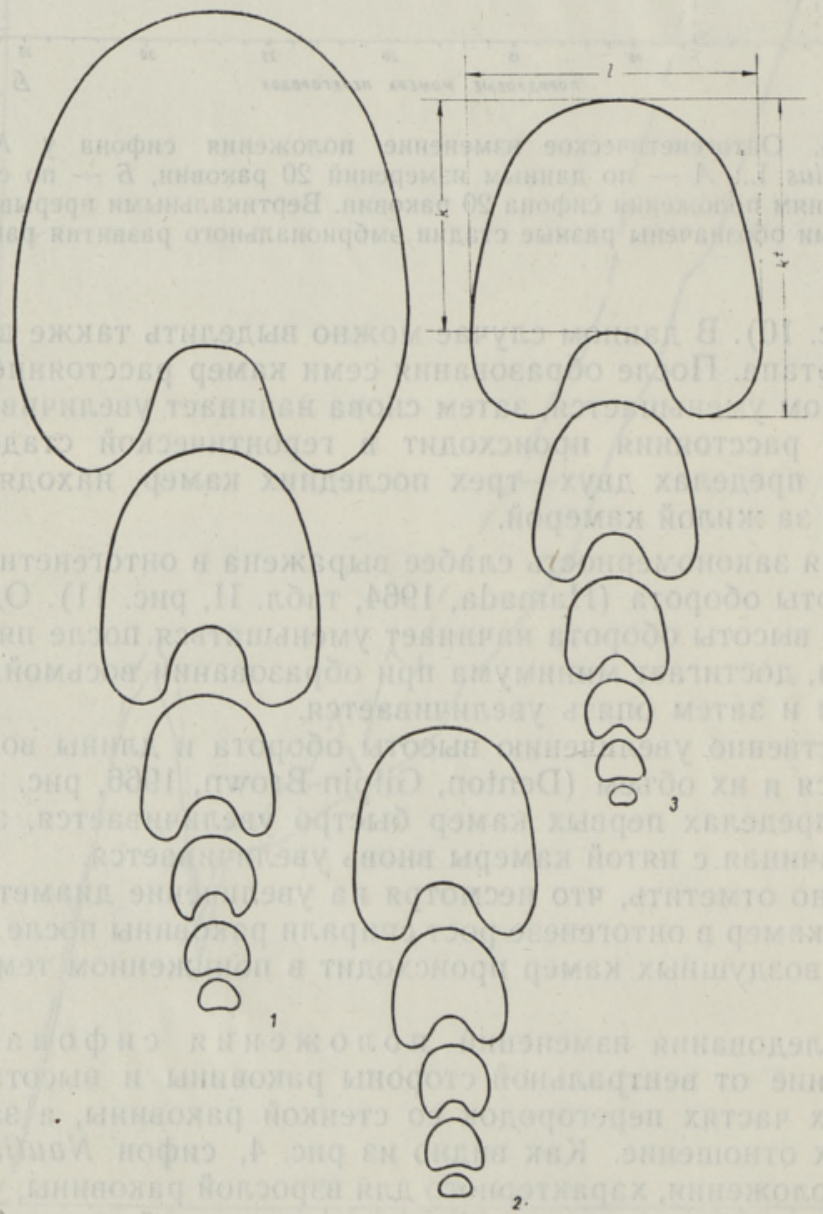

Рис. 6. Поперечные разрезы оборотов раковины Nautilus pompilius L. $(\times 0,5): 1$ - экз. № Co 22,2 - экз. № Co 23 , 3 - экз. № Со $24 ; l$ - ширина оборота, $k$ - высота оборота, $k^{t}$ - тотальная высота оборота.

Для вычисления отношения высоты оборота к его ширине (рис. 6) в первом случае использовались ширина и тотальная высота оборота (рис. 7) и во втором - высота оборота. Независимо от методики изме- 
рения изменения отношений размеров оборота происходят по степенной функции $\left(y=b x^{a}\right)$. На ранних стадиях развития раковины Nautilus pompilius отношения размеров оборотов быстро увеличиваются до определенных пределов, а затем уменьшаются. Наименьшие отношения размеров оборотов установлены в устьевых частях жилой камеры, которые даже не брали в расчет при вычислении средних значений размеров оборотов (рис. 7).

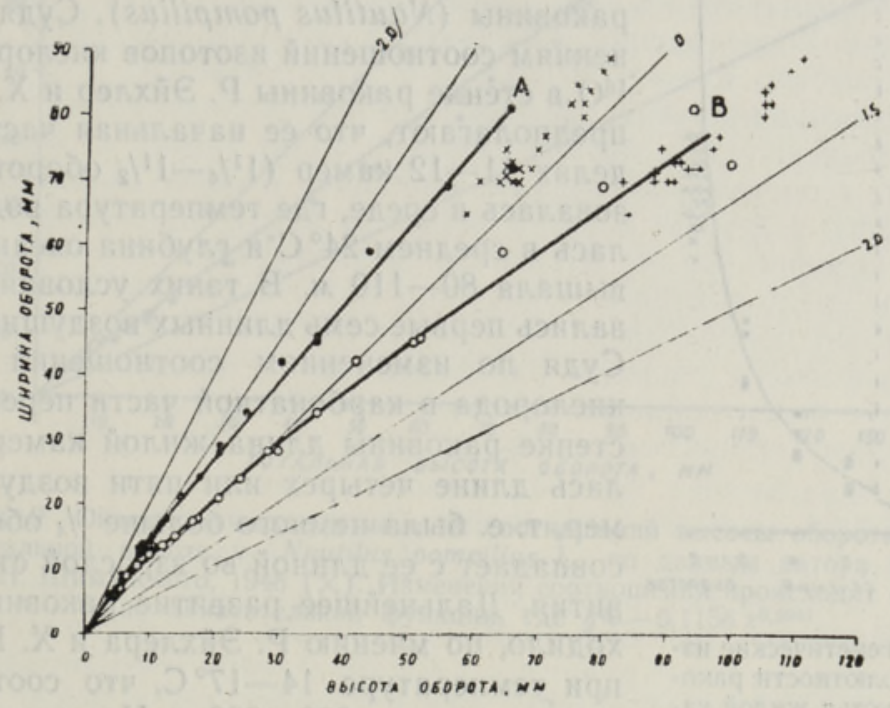

Рис. 7. Изменения соотношений высоты оборота к его ширине (О) и ширине устья раковины $(X)$; и тотальной высоты оборота к его ширине $(\mathrm{O})$ и ширнне устья раковины $(+)$ у Nautilus pompilius L. Изменения соотношений оборотов в первом случае происходят согласно показательной функции, где $\bar{y}=0,2101 x^{0,9335}(A)$, и во втором случае, где $\vec{y}=0,2410 x^{0,8287}(B)$.

Изменения очертаний поперечного сечения оборотов изображены на рис. 6, где зарисовки оборотов одного поперечного разреза раковины расположены в один ряд. На ранних стадиях развития раковины Nautilus pompilius обороты овального очертания вытянуты больше по ширине, чем по высоте, и имеют слабо выраженный контактовый желобок. После образования $1 \frac{1}{4}$ оборота контактовый желобок сильно углубляется и тотальная высота оборота быстро увеличивается. Поперечное сечение оборота принимает форму трапеции с округлыми вентро- и дорсолатеральными краями.

Изменения степени ин волютности оборотов у четырех раковин Nautilus pompilius показана на рис. 8. Как видно, более четкие изменения происходят после образования $1 \frac{1}{4}$ оборота. В устьевой части жилой камеры инволютность раковины уменьшается. Для характеристики этого показателя использовались и соотношения минимальной и максимальной высоты оборота или апертуры (Шиманский, 1948) (рис. 9).

У мбон альное отверстие у Nautilus pompilius сравнительно большое и заполнено раковинным веществом. Его размеры (длина от 1,4 до 2,2 мм и ширина от 0,7 до 1,3 мм, рис. 10) почти равны размерам умбонального отверстия Nautilus macromphalus. Форма его в виде запятой обусловлена̨ тем, что самый апикальный конец раковины рогообразно согнут, и она начинает свертываться после образования третьей камеры. 
Стенка раковины (Mutvei, 1968, 1964) состоит из четырех слоев: внутреннего призматического, перламутрового, внешнего призматического и конхиолинового слоев. Перегородки сложены из перламутрового, призма-

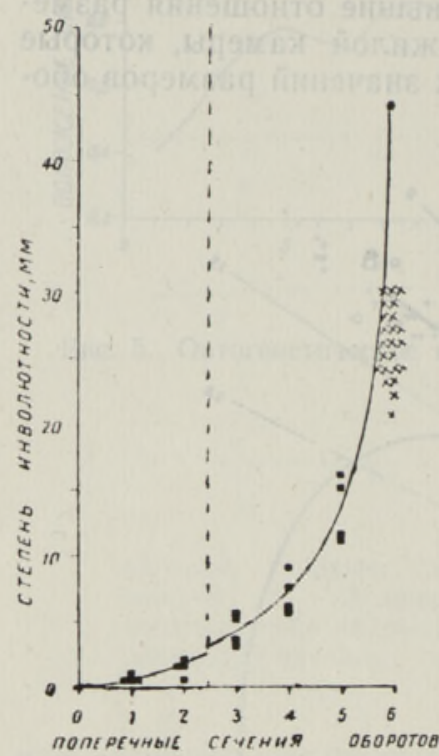

Рис. 8. Онтогенетические изменения инволютности раковины (国 и устья жилой камеры $(\bar{x})$ у Nautilus pompilius $\mathrm{L}$. тического и конхиолинового слоев. Интересные данные получены Р. Эйхлером и Х. Риштедтом (Eichler, Ristedt, 1966) о соотношении изотопов кислорода и углерода в карбонатной части раковины (Nautilus pompilius). Судя по изменениям соотношений изотопов кислорода ${ }^{18} \mathrm{O}$ и ${ }^{16} \mathrm{O}$ в стенке раковины Р. Эйхлер и Х. Рнштедт предполагают, что ее начальная часть, в пределах $11-12$ камер $\left(1^{1 /} / 4-1^{1} / 2\right.$ оборота), образовалась в среде, где температура воды равнялась в среднем $24^{\circ} \mathrm{C}$ и глубина океана не превышала $80-110$ м. В таких условиях образовались первые семь длинных воздушных камер. Судя по изменениям соотношений изотопов кислорода в карбонатной части перегородок и стенке раковины длина жилой камеры равнялась длине четырех или пяти воздушных камер, т. е. была немного больше $1 / 4$ оборота, что совпадает с ее длиной во взрослой стадии развития. Дальнейшее развитие раковины происходило, по мнению Р. Эйхлера и Х. Риштедта, при температуре $14-17^{\circ} \mathrm{C}$, что соответствует глубине океана $200-300$ м. Изменения соотношений изотопов кислорода хорошо совпадают с изменениями роста раковины.

Изменения соотношений изотопов углерода ${ }^{13} \mathrm{C}$ и ${ }^{12} \mathrm{C}$ в карбонатной части раковины Nautilus pompilius имеют более сложный характер, чем кислорода, и происходят с некоторым опозданием. Так, в карбонатном веществе перегородок более резкие изменения соотношений изотопов углерода наблюдаются только после образования восьмой септы и в стенке раковины после 13 перегородки. На более ранних стадиях развития раковины отмечены небольшие изменения в септе после образования второй или третьей перегородки и в стенке раковины после образования пятой перегородки, а на более поздних стадиях развития - в перегородке после 15 или 18 камеры.

Итак, первые изменения в строении раковины начинаются уже на самых ранних стадиях ее развития, как и у нижнепалеозойских представителей Tarphyceratida (Стумбур, 1960). Они выражаются в изменениях как положения сифона, так и соотношения изотопов углерода после образования двух-трех перегородок. Судя по перемене изотопов углерода в стенке раковины длина жилой камеры достигала шестой перегородки. Для этой стадии развития раковины свойственно исчезновение юношеской скулыптуры, появление окраски взрослого индивида и резкое свертывание раковины в спираль. В некоторой степени все эти изменения совпадают с переменой соотношений изотопов кислорода в перегородках.

Сифон достигает положения, характерного для взрослой раковины, уже в пятой воздушной камере, а очертание поперечного сечения и контактовый желобок становятся подобными взрослым раковинам после образования $1 \frac{1}{4}$ оборота (около 9 камер). 


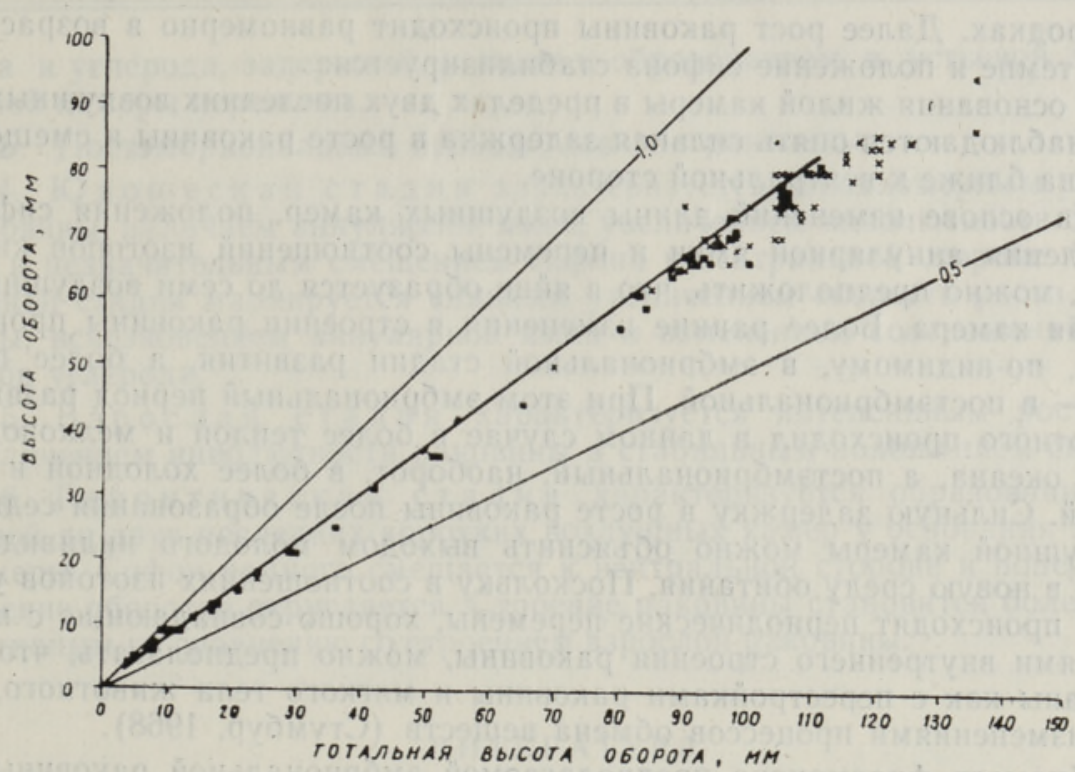

Рис. 9. Онтогенетические изменения соотношений высоты оборота к его тотальной высоте у Nautilus pompilius L. по данным автора (目 и В. Н. Шиманского, 1948 (Х). Изменения соотношений происходят согласно показательной функции, где $\bar{y}=-0,1156 x^{0,9941}$.

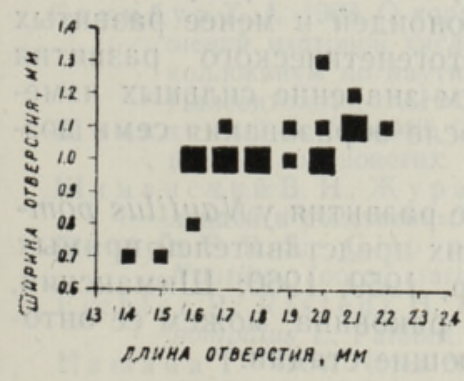

Рис. 10. Изменения размеров умбонального отверстия раковины Nautilus pompilius L.

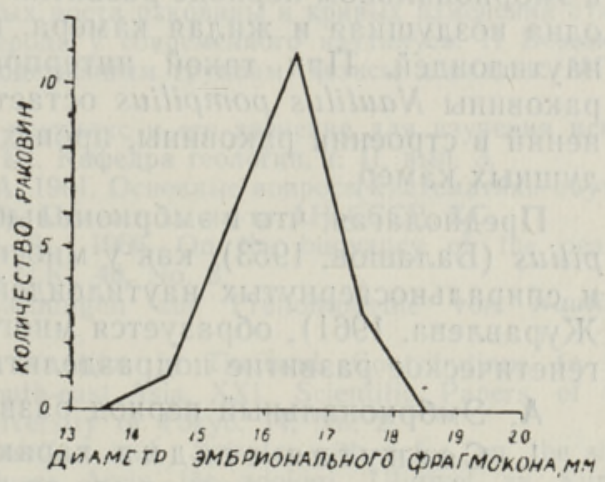

Рис. 11. Вариация диаметра эмбрионального фрагмокона у Nautilus pompilius L.

После образования семи воздушных камер рост раковины замедляется и уровень колебаний положения сифона изменяется. Перестройка внутреннего строения раковины сопровождается значительным изменением соотношений изотопов кислорода и углерода в седьмой или восьмой перегородке и в стенке раковины у 11-12 или 13 перегородок.

С восьмой камерой совпадает начало образования в септах аннуляр. ной ямки. Далее в пределах нескольких камер аннулярная ямка углубляется (табл. II, фиг. 1, 2) и сифон смещается ближе к вентральной стороне, но скоро аннулярная ямка начинает уменьшаться и в пределах 1821 камеры исчезает. Этот период развития раковины характеризуется относительно малой и неравномерной скоростью роста. В пределах 1518 камер наблюдается и изменение соотношений изотопов углерода в пе- 
рогородках. Далее рост раковины происходит равномерно в возрастающем темпе и положение сифона стабилизируется.

У основания жилой камеры в пределах двух последних воздушных камер наблюдаются опять сильная задержка в росте раковины и смещение сифона ближе к вентральной стороне.

На основе изменений длины воздушных камер, положения сифона, появления аннулярной ямки и перемены соотношений изотопов кислорода, можно предположить, что в яйце образуется до семи воздушных и жилая камера. Более ранние изменения в строении раковины происходили, по-видимому, в эмбриональной стадии развития, а более поздние - в постэмбриональной. При этом эмбриональный период развития животного происходил в данном случае в более теплой и мелководной воде океана, а постэмбриональный, наоборот, в более холодной и глубокой. Сильную задержку в росте раковины после образования седьмой воздушной камеры можно объяснить выходом молодого индивида из яйца в новую среду обитания. Поскольку в соотношениях изотопов углерода происходят периодические перемены, хорошо совпадающие с изменениями внупреннего строения раковины, можно предполагать, что они связаны как с перестройками раковины и мягкого тела животного, так и с изменениями процессов обмена веществ (Стумбур, 1968).

Диаметр фрагмокона предполагаемой эмбриональной раковины колеблется от 14,5 до 18,5 мм (рис. 11). Разница между минимальным и максимальным диаметрами составляет 4 мм. В таких же пределах могли меняться и размеры яиц, откладываемых животными. Некоторые исследователи (Hamada, 1964; Eichler, Ristedt, 1966; и др.) предполагают, что в эмбриональном периоде развития у Nautilus pompilius образуется лишь одна воздушная и жилая камера, как у аммоноидей и менее развитых наутилоидей. При такой интерпретации онтогенетического развития раковины Nautilus pompilius остается неясным значение сильных изменений в строении раковины, происходящих после образования семи воздушных камер.

Предполагая, что в эмбриональном периоде развития у Nautilus pompilius (Балашов, 1953), как у многих вымерших представителей прямых и спиральносвернутых наутилоидей (Стумбур, 1959, 1960; Шиманский, Журавлева, 1961), образуется многокамерная раковина, можем ее онтогенетическое развитие подразделить на следующие стадии.

А. Эмбриональный период развития раковины.

1. Согнутая стадия характеризуется сильно отличным положением сифона от положения его во взрослой раковине и дугообразно согнутой раковиной, покрытой юношеской скульптурой. В этой стадии образуется от двух до трех воздушных и жилая камера. Конец стадии маркируется первыми изменениями соотношений изотопов углерода и положения сифона.

2. Гироцератитовая стадия, где происходят сильные изменения внутреннего строения и внешнего облика раковины. В этой стадии раковина состоит примерно из пяти воздушных и жилой камеры. Сифон занимает примерно такое же положение, как во взрослой раковине. Исчезает юношеская скульптура и появляются полосы окраски, подобные взрослой раковине. Раковина сильно сворачивается в спираль.

3. С вернутая стадия, где происходит подготовка выхода молодого индивида из яйца. К этой стадии относится образование двух последних эмбриональных воздушных камер. Им характерны небольшие задержки в росте и стабильное положение сифона. Конец этой стадии маркируется значительным изменением соотношений изотопов кисло- 
рода и углерода, задержкой в росте и образованием в устьевой части жилой камеры пережима.

Б. Постэмбриональный период развития раковины.

4. Юношеск а я с т д и я характеризуется неравномерным ростом раковины, наличием аннулярной ямки, увеличением инволютности оборотов и незначительным смещением сифона к вентральной стороне. Конец данной стадии маркируется сильным увеличением скорости роста раковины, исчезновением аннулярной ямки и изменением соотношений изотопов углерода.

5. Взрослая стадия характернзуется интенсивным ростом и увеличением инволютности раковины и стабильным положением сифона.

6. Геронтическая стадия характеризуется образованием от одной до двух последних коротких воздушных камер у основания жилой камеры. Сифон немного смещается к вентральной стороне и поперечное сечение оборотов округляется. Строение раковины становится более примитивным по сравнению со строением взрослой раковины.

\section{ЛИТЕРАТУРА}

Б а л а шов 3. Г. 1953. К вопросу 'о развитии начальных камер у наутилондей. Вестн. Ленингр. ун-та. Сер. биол., № 10.

С тум 6 у р Х. А. 1959. Об эмбриональных раковинах некоторых ордовикских Tarphyceratida. Палеонтол. ж., № 2.

С т у м 6 у р Х. 1960. О разных путях развитня наутилондей. Изв. АН ЭССР. Сер. физ.матем. и техн, наук, IX, № 4.

С т у м 6 у р Х. А. 1968. О корреляции кривых роста раковины и кривых изменений отношений изотопов кислорода и углерода у современного наутилуса. II Всесоюз. коллоквиум по наутилоидеям и родственным группам. Тезисы докладов. МГУ. Палеонтол. ин-т АН СССР. М.

Ш и м а нский В. Н. 1948. Современный наутилус и его значение для изучения ископаемых головоногих. Уч. зап. МГПИ. Кафедра геологии, т. II, вып, 3.

Ш и м а н ки й В. Н., Ж у р ав ле в а Ф. А. 1961. Основные вопросы систематики наутилондей и родственных им групп. Тр. Палеонтол. ин-та АН СССР, ХС.

Denton F. R. S., Gilpin-Brown J. B. 1966. On the buoyancy of the pearly Nautilus. Journ. marine Biol. Ass. U.K., 46, No. 3.

Eichler R., Ristedt H. 1966. Untersuchungen zur Frühontogenie von Nautilus pompilius L. Paläont. Z., $40,3 / 4$.

$\mathrm{Hamada}$ T. 1964. Notes on the Driften Nautilus in Thailand. Contributions to the Geology and Palaeontology of South-east Asia, XXI. Scientific Papers of the College of General Education. University of Tokyo, 14, No. 2.

Mutvei H. 1964. On the shells of Nautilus and Spirula with notes on the shell secretion in non-cephalopod molluscs. Arciv för zoologi. Utigivet av Kungl. Svenska Vetenskapsakademien, 16, Nr. 14.

Mutvei H. 1967. On the microscopic shell structure in some Jurassic ammonoids, N. Jb. Geol. Paläont. Abh. Stuttgart, 129, Nr. 2.

Mutvei H. 1968. Structure of the wall of siphonal tube. II Всесоюз. коллоквиум по наутилондеям и родственным группам. Тезисы докладов. МГУ. Палеонтол. ин-т AH CCCP. M.

Управление геологии
Совета Министров Эстонской ССР

Поступнла в редакцию 29/V 1974

\section{H. STUMBUR}

\section{TÄNAPÄEVA NAUTILUSE KOJA BIOMEETRILINE ISELOOMUSTUS}

Artiklis on esitatud andmed 26 Nautilus pompilius'e ja ühe Nautilus macromphalus'e koja elukambri ja gaasikambrite pikkuse, sifo asendi, keerme kõrguse ja laiuse, koja involuutsuse, nabaava pikkuse ja laiuse ning embrüonaalse fragmookoni diameetri muutlikkuse kohta. Koja arengustaadiumide eristamiseks on kasutatud ka kirjanduses koja 
karbonaatse osa hapniku ja süsiniku isotoopide kohta avaldatud andmeid (Eichler, Ristedt, 1966).

Koja embrüonaalne arenguperiood jaotatakse analoogiliselt Tarphyceratida esindajatele (Стумбур, 1959) siseehituse, väliskuju ning hapniku ja süsiniku isotoopide suhete muutuste järgi kolme (kõverdunud, gürotseratiitsesse ja keerdunud) staadiumi. Nende postembrüonaalses arenguperioodis eristatakse noor-, täis- ja raugaiga.

\section{H. STUMBUR}

\section{BIOMETRICAL CHARACTERISTICS OF THE SHELL OF A LIVING} NAUTILUS

Measurement data are presented concerning the mutations of the length of the body chamber, length of the air chambers, position of the siphuncle, height and width of the volution, involuteness of the shell, width and length of umbilical perphoration, and the diameter of the embryonal phragmocone of 26 shells of Nautilus pompilius L. and one shell of Nautilus macromphalus Sow.

The embryonal period of the development of the shell is divided, analogically to that of the representatives of Tarphyceratida (Стумбур, 1959) into cyrtoconic, gyrocone, and evolute stages, and the postembryonal - into neonic, ephebic and gerontic stages. 